\author{
COLLEGE OF AGRICULTURE \\ AGRICULTURAL EXPERIMENT STATION \\ BERKELEY, CALIFORNIA
}

\title{
THE EFFECTS OF ALKALI ON CITRUS TREES
}

BY

W. P. KELLEY AND E. E. THOMAS

BULLETIN No. 318

JANUARY, 1920

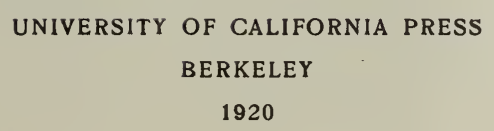




\section{EXPERIMENT STATION STAFF}

\section{HEADS OF DIVISIONS}

David P. Barrows, Ph.D., LL.D., President of the University.

Thomas Forsyth Hunt, Dean.

Edward J. Wickson, Horticulture (Emeritus).

Walter MUlford, Forestry, Director of Resident Instruction.

Herbert J. WeibBer, Director Agricultural Experiment Station.

B. H. Crocheron, Director of Agricultural Extension.

Hubert E. Van Norman, Vice-Director; Dairy Management.

James T. BarretT, Acting Director of Citrus Experiment Station; Plant Pathology.

William A. Setchell, Botany.

MYER E. JAFFA, Nutrition.

Charles W. Woodworth, Entomology.

RALPH E. SMith, Plant Pathology.

J. Eliot Coit, Citriculture.

John W. Gilmore, Agronomy.

Charles F. Shaw, Soil Technology.

JoHN W. GREGG, Landscape Gardening and Floriculture.

Frederic T. Bioletti, Viticulture and Enology.

Warren T. Clarke, Agricultural Extension.

JoHn S. Burd, Agricultural Chemistry.

Charles B. Lipman, Soil Chemistry and Bacteriology.

Clarence M. Haring, Veterinary Science and Bacteriology.

Ernest B. BABCOCK, Genetics.

Gordon H. True, Animal Husbandry.

Fritz W. Woll, Animal Nutrition.

W. P. Kelley, Agricultural Chemistry.

H. J. Quayle, Entomology.

Elwood MEad, Rural Institutions.

H. S. ReEd, Plant Physiology.

L. B. Batchelor, Orchard Management.

J. C. Whitten, Pomology.

FRANK ADAMS, Irrigation Investigations.

C. L. Roadhouse, Dairy Industry.

F. L. Griffin, Agricultural Education.

John E. Dougherty, Poultry Husbandry.

S. S. ROGERS, Olericulture.

L. J. Fletcher, Agricultural Engineering.

Edwin C. Voorhies, Assistant to the Dean.

\section{CITRUS EXPERIMENT STATION}

Division of Agricultural Chemistry
W. P. Kelley
*A. B. Cummins
E. E. Thomas
S. M. Brown

* Resigned June 1, 1919. 


\title{
THE EFFECTS OF ALKALI ON CITRUS TREES*
}

\author{
By W. P. KELLEY AND E. E. THOMAS
}

\section{INTRODUCTION}

It is generally believed that citrus trees are especially sensitive to alkali. One of the best known investigations on the effect of alkali on citrus was published by Loughridge in $1898 .^{1}$ In this paper it was pointed out that orange trees may be severely injured by the use of saline irrigation water. From studies on certain groves near Corona, California, it was found that severe injury had been produced as a result of irrigating with saline water from Lake Elsinore for a period of from three to four years.

Analysis of the water showed it to contain 917 parts per million sodium chloride (common salt), 377 parts per million sodium sulfate (glauber salt), and 391 parts per million sodium carbonate (black alkali). Loughridge concluded that the injury to the trees was due directly to the corrosive action and puddling effect of the black alkali and indirectly to the antiseptic action of the sodium chloride on the bacterial processes of the soil.

The effects were more pronounced in certain groves than in others. Inherent differences in the soil apparently exerted an influence on the depth to which the water penetrated and, therefore, caused the salts to accumulate in greater quantities in the upper layers of the soil of certain groves than of others. On the whole, the effects were roughly proportional to the concentration of the alkali salts that had accumulated in the zone occupied by the roots of the trees.

The results of this investigation indicated that citrus trees are quite sensitive to alkali, and that the length of time a given supply of saline irrigation water may be used without producing injury depends mainly on the rate the injurious constituents accumulate in the layers of soil occupied by the roots of the trees.

In 1900 Hilgard $^{2}$ pointed out that citrus trees are especially sensitive to sodium chloride. He called attention to the previous work at

* Paper No. 53, University of California, Graduate School of Tropical Agriculture and Citrus Experiment Station, Riverside, Calif.

1 Effect of Alkali on Citrus Trees. Annual Report, Calif. Agr. Exp. Sta. 1897-8, pp. 99-113.

2 Nature, Value and Utilization of Alkali Lands. Calif. Agr. Exp. Sta. Bull. 128 (1900), p. 28. 
Corona in which it had been found that 2520 pounds per acre of sodium chloride distributed through the soil to a depth of four feet, caused an orange tree to become completely leafless, while another tree nearby, where the soil was similar in other respects, but contained only 720 pounds per acre of sodium chloride, was much less severely injured. "Here it is apparently the excess of common salt to which the difference is due."

In 1901 Loughridge $^{3}$ called attention to the extreme sensitiveness of the lemon tree. He said: "The lemon seems to be the least tolerant of all of the fruit trees, for it was stunted by 1440 pounds common salt per acre, distributed through four feet depth, and was killed by 1900 pounds combined with 1900 pounds carbonate of soda."

In harmony with the conclusions of Loughridge and Hilgard, recent investigations by the writers have shown that different varieties and species of citrus trees are quite sensitive to alkali, especially so in the case of the lemon, and that after a few years irrigation with saline water, both lemon and orange trees may be severely injured. Again, it has been found that the effects produced by a given supply of impure irrigation water may, for a time at least, be extremely variable even in different portions of the same grove. Part of this variability, as shown below, is probably due to differences in the depth to which the water penetrates, which in turn affects the rate at which the salts accumulate in the root zone.

Experience in various localities has shown that, under certain conditions, continued irrigation with comparatively pure water also tends to hasten the accumulation of injurious amounts of soluble salts. Several hundred thousand acres located in different parts of California, which were free from injurious amounts of alkali previous to the introduction of irrigation, have since become veritable alkali lands. Seepage, together with a rising water table incident to over-irrigation, have been the principal means by which the salts have been brought up from below and deposited near the surface. Small areas of citrus groves have already become heavily charged with alkali by this means.

In the course of investigations on the nutrition of citrus trees, we have devoted considerable study to certain phases of the alkali problem. Early in this work, it became evident that the existing state of knowledge was inadequate. The symptoms of alkali injury have not been recognized clearly. The relations of fertilizers to the problem, and especially the effect of applying irrigation water containing alkali salts, are inadequately understood and appreciated.

3 Tolerance of Alkali by Various Cultures. Calif. Agr. Exp. Sta. Bull. 133 (1901), pp. 14-16. 
It is commonly held that alkali injury is mainly, if not entirely, due to excessive concentration as such. In the course of this work, it has become evident, however, that injury may be produced under certain conditions where the total concentration is relatively low. The data obtained in a study of this phase of the subject afford the basis for an interesting hypothesis which will be presented elsewhere and further work is in progress. The discussion in this bulletin will be confined mainly to the effects of excessive concentration.

As this work has progressed, it has become increasingly evident that many of the citrus growers of California have not sufficiently grasped the significance of alkali in citrus culture. Especially is this true in regard to the bearings of impure irrigation water on the accumulation of alkali in the soil. Fortunately, a large percentage of the citrus soils was free from alkali previous to the introduction of irrigation and very much of it still remains free. There are considerable areas located in several districts, however, where harmful amounts of alkali have accumulated as a result of applying saline irrigation water and still other areas, not yet seriously injured, where alkali is accumulating at present as a result of orchard practices which, if continued, will ultimately produce injury.

This bulletin will be devoted to a discussion of results obtained in connection with a study of a considerable number of citrus groves in different localities in California. The investigations reported herein deal mainly with the effects of alkali rather than with means of overcoming the injury. It is undoubtedly a matter of practical importance for citrus growers to be able to recognize the effects of alkali and especially to appreciate the relationships between existing orchard practices and the accumulation of alkali.

Unfortunately, the present state of knowledge does not yet make it possible to predict with as great a degree of certainty as is desirable, what the effects of a given amount of alkali will be, or how long a given saline irrigation water may be applied before producing injury. The extreme variability of soils and the inadequacy of knowledge concerning the fundamental relationships between salts and soils, and salts and plant growth, add to the difficulty. Despite these facts, information of some practical importance has been obtained.

The investigations reported herein should be looked upon as being preliminary to a study of methods of combating alkali in citrus groves. It is hoped that this discussion will enable citrus growers to recognize the effects of alkali, to appreciate the seriousness of alkali in citrus culture, to apprehend more clearly the relationships between irrigation and the accumulation of alkali, and to see that the applica- 
tion of certain fertilizers, especially nitrate of soda, may, under certain conditions at least, bear a very important relation to the accumulation of alkali. With this knowledge, it is hoped that practical citrus growers will be able to adjust their irrigation and fertilizer practices in such a way as to retard the further spread of alkali and thus prevent its accumulation in many groves that have, as yet, not been seriously injured.

\section{SYMPTOMS OF ALKALI INJURY}

Different varieties and species of citrus trees are affected differently by alkali. Lemon trees show the effects by a pronounced yellowing of the margins and burning of the tips of the leaves, followed by unusually heavy shedding of the leaves in the latter part of the winter and spring. The subsequent new growth may appear to be quite normal and vigorous for several months, but later a large portion of the leaves turn yellow in irregularly shaped areas around the margins and fall excessively. In the presence of excessive concentrations of salts, especially chlorides, complete defoliation may take place. Mottle leaf frequently occurs, and sometimes chlorosis. Both the quality and quantity of the fruit are impaired.

Orange trees also show the effects of alkali in different ways. On certain soils, mottle leaf is one of the first symptoms. In some localities, the older leaves assume a brownish hue and tend to curl slightly. Rather sudden defoliation takes place, especially when excessive amounts of chloride occur, followed later by a profuse growth of new shoots. The leaves of the new growth are likely to be undersized and paler in color than normally. With especially high concentrations of sulfates and bicarbonates in the soil, orange leaves become chlorotic and strikingly similar to that condition referred to by Hilgard ${ }^{*}$ as occurring on highly basic soils. The smaller twigs may be killed. Frequently the leaves are abnormally small on one portion of a tree, and full-sized on others.

Premature shedding of the leaves takes place with both oranges and lemons affected by small amounts of alkali, which may be protracted throughout the greater part of the winter months, thus greatly reducing the number of leaves remaining on the trees at the close of the dormant period. Navel oranges are more sensitive than Valencias, and Eureka lemons more sensitive than Lisbons. In general, lemon trees are more sensitive than orange trees. Neither orange nor lemon

4 Marly subsoils and the Chlorosis or Yellowing of Citrus Trees. Calif. Agr. Exp. Sta. Cir. No. 27 (1906). 
trees reach their usual size on soil that contains injurious amounts of alkali.

It has been found that orange trees affected by alkali are unusually susceptible to injury from adverse climatic conditions. Hot winds burn the young leaves and frosts produce more serious injury than with normal trees. Alkali injury is also accentuated by the lack of care, such as improper tillage, the insufficient use of manure or other fertilizers, and withholding irrigation, thereby allowing the soil to become too dry. If the soil by allowed to dry out excessively, the concentration of alkali in the soil moisture may become harmful, while a more abundant supply of water would so dilute the salts present as to reduce the concentration to a point where normal growth could take place.

\section{THE EFFECTS OF IRRIGATION WATER}

Despite the wide publicity that has been given the subject of irrigation waters and the many analyses that were published by Hilgard in the reports of the California Station, our studies in the different citrus districts suggested the desirability of making a survey of the irrigation water in use at present. More than a thousand samples have been analyzed. It has been found that the vast majority are practically free from alkali. Especially is this true of the water that is drawn from points located near the large watersheds, such, for example, as the Sierra Nevada and the San Bernardino mountains. Usually the wells that are located near the course of streams that originate in those mountains are also sufficiently pure.

On the other hand, wells located at some distance from the large watersheds and relatively large streams that themselves originate directly in the mountains, show a wide range in composition. A considerable number of such wells contain notable amounts of salts. These are widely distributed over a considerable number of citrus districts in several counties. In certain localities the dissolved salts are predominantly chlorides, others sulfates and in still others bicarbonates. A few wells have been found to contain large amounts of nitrates.

The results of this survey are, on the whole, in close agreement with the published conclusion of Dr. Hilgard. We quote from him as follows: ${ }^{5}$

"The investigations made by the Station have shown that aside from the frequently saline character of the well and even the artesian

5 Calif. Agr. Exp. Sta. Bull. 128 (1900), p. 31. 
waters of the petroleum bearing regions of the State in the coast ranges, the streams of that region, especially the smaller ones, are sometimes too strongly charged with alkali (in this case largely the sulfates of soda and magnesia) to be suitable either for irrigation or domestic use. Towards the end of the dry season, even the larger streams of the southern coast ranges, with their diminished flow, sometimes show an excess of salts. This seems also to be true of the San Jacinto river, which feeds Elsinore Lake." On the other hand, he says: "The waters flowing from the Sierra Madre, south of the Tehachapi range, are throughout of excellent quality for irrigation purposes, as are all those flowing from the Sierra Nevada. The same is true of the artesian waters of the valley of southern California, from Los Angeles east to Redlands."

A considerable number of groves that have been irrigated with saline water have been under close observation for one or more years. As a means of securing information on the effects, soil samples, drawn with a one-inch soil tube, have been analyzed and wherever possible adjacent areas that have been irrigated with comparatively pure water, or virgin soil, have also been sampled. Some of the results are submitted below, together with analyses of the irrigation waters that have been applied.

The analytical results are expressed as parts per million of the soil or water. In contrast to previous publications, we have not attempted to estimate the amounts of the several salts present. The state of present knowledge does not make it possible to determine definitely the actual amounts of the different salts that occur in complex mixtures, such as irrigation waters or soils. By analysis the components of the differént salts may be determined, but while various schemes have been employed for calculating the amounts of salts present, all of them are more or less arbitrary and have little justification in modern chemistry. Accordingly, the analytical data are submitted as determined without calculating the theoretical salt combinations.

The analyses recorded in table 1 have been chosen to show the wide range in composition found among the irrigation supplies. Some of these contain large amounts of salts, others lesser amounts. As will be pointed out more fully below, the effects of some of these waters have been extremely injurious. Sample No. 84 represents suitable water. This sample, drawn from wells located near the San Bernardino Mountains, fairly represents the main supplies of mountain water of southern California, the effects of which have been entirely satisfactory. 
It is not necessary to discuss the amounts of, and variations among, the individual constituents of these waters. Casual observation of the analyses will suffice to show that there is a wide range of difference in the content of total dissolved materials and that a number of the individual constituents occur in certain samples in relatively large amounts. The most significant differences in these waters probably lie in the chlorine and sodium. The unusually high nitrate content of sample No. 119 is a matter of special interest. Where such water is used for irrigation, it is highly improbable that nitrogenous fertilizers will be needed.

The variations found among samples that contain relatively large amounts of salts, such, for example, as Nos. 642 and 643, are probably of little practical significance. On the other hand, samples Nos. 103 and 105 contain still greater amounts of salts, especially so in the case of the latter. Sample No. 150 is of intermediate composition and represents a type of water that is being used at present on several thousand acres of citrus in California. As will be pointed out later, the use of this water on a lemon grove for a period of approximately twenty years, produced definite injury.

The numbers of pounds of a given constituent that will be added to the soil by an irrigation water may be readily calculated from the analysis. For example : an acre foot of water, No. 119, which contains 1479 parts per million soluble solids, will supply the soil 3993 pounds of solids, while an acre foot of No. 84, containing 222 parts per million, will add only 599 pounds. In view of the fact that the amounts of water applied varies widely in different localities and in different years in a given grove, it is not possible to state the exact amounts of salts that have been added to the soil in a given case. It is only possible at present to make qualitative comparisons among the groves. It is evident, however, that large amounts of alkali must necessarily have been added to the soil where such water as Nos. 119, 642 and 643 have been applied. Still greater amounts must have been added in a given period with Nos. 103 and 105, while with No. 150, the rate of salt addition has been considerably less.

During the past eight years, several hundred acres of orange orchards located near Riverside, which were previously irrigated with suitable water, have been irrigated with saline water similar to samples Nos. 119, 642 and 643. Other groves adjacent to these have been irrigated from the beginning with comparatively pure water (No. 84). So far as can now be determined, the soil in this immediate locality was reasonably uniform and free from alkali previous to planting the orchards. The soil is of a sandy loam character, reason- 
ably deep and free from hardpan. Throughout this district, the soil is deficient in organic matter and nitrogen, the liberal application of both of which is required for successful citrus culture.

The orange trees are about twenty-four years old. A number of these groves have been under close observation for a period of about three years. A large portion of the trees irrigated with the saline water have already been severely injured; some of them are almost dead and a large portion unprofitable. The degree of the injury is much more pronounced at the present time (1919) than it was in 1917, while in 1916 injurious effects had scarcely begun to appear. The accompanying photographs, plates 1 and 2, illustrate the effects and show the appearance of the trees in the spring of 1919. They show the striking contrast between the effects of good irrigation water and water containing alkali salts. In portions of the groves where the saline water has been applied, excessive defoliation has taken place several times. Many of the smaller branches have died and the new foliage has shown excessive mottle leaf.

Soil samples from a number of these groves have been analyzed. Some of the results are submitted in tables $2,3,4,5$ and 6 . The data show that the total soluble salt content of the soil and the amounts of certain individual constituents have been greatly increased as a result of irrigating with saline water. The chlorine and sodium content have been increased to the greatest extent. Other constituents have also been augmented considerably.

The data show a direct relationship between the salt content of the soil and the composition of the irrigation water, and the condition of the orange trees is positively correlated with the salt content. It is evident, however, that orange trees are extremely sensitive. The total concentration of soluble matter in a number of the samples was not more than 0.10 per cent (1000 parts per million), even where the trees have been severely injured. The soil samples represent composite mixtures of a considerable number of cores, taken at random from the spaces between the trees where the irrigation waters have been applied. Under the prevailing system of furrow irrigation soluble salts tend to accumulate in greatest amounts between the irrigation furrows and in the unirrigated spaces between the trees, owing to lateral movement. Consequently, higher concentrations probably occur in localized areas between the furrows, than were found in the samples analyzed. While orange trees are more sensitive to alkali than many other crops, it is reasonably certain that with the continued use of these waters the soil will become so heavily charged with alkali as to impair its usefulness for the more resistant crops. 
The data in tables 4,5 and 6 show that the salts have evidently penetrated to considerable depths. Samples were taken in three groves to a depth of seven feet, two of which have been irrigated with saline water (No. 643), the other with comparatively pure water (No. 84).

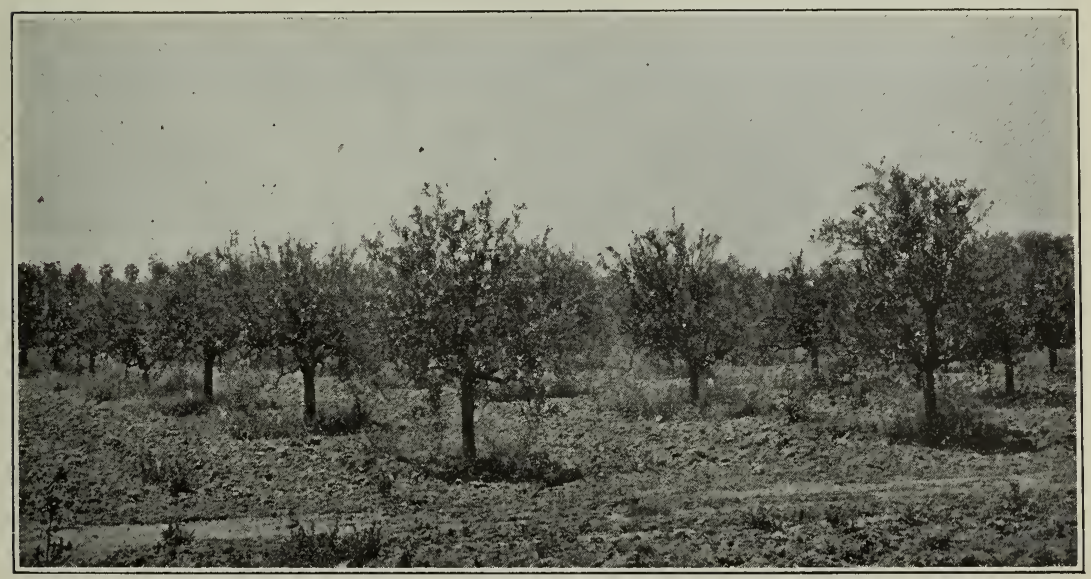

Fig. 1.-Orange trees irrigated with saline water, No. 643.

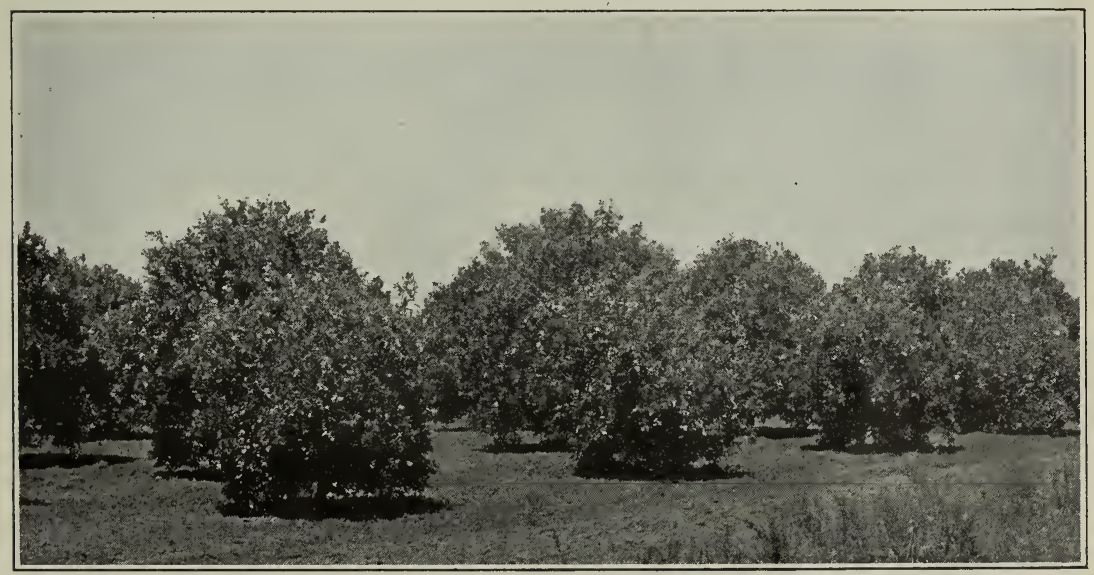

Fig. 2.-Orange trees irrigated with good water, No. 84 .

The analyses establish the fact that the salts have penetrated deeply. The data suggest that the penetration has even reached deeper than seven feet, but samples have not been drawn from greater depths.

The analyses of samples from the different groves that have been irrigated with pure water indicate that the original soil must have varied considerably. The variations are not surprising, however, since 
the different groves from which these samples were taken are located considerable distances apart. It may be mentioned in passing, that more or less mottle leaf occurs in many of the groves in this locality that have been irrigated with comparatively pure water. In such cases, the cause of the mottle leaf inheres in the soil itself: Considerably more mottle leaf occurs in grove $\mathrm{E}$ than in groves $\mathrm{M}$ or $\mathrm{S}$. It is interesting to note that the soil of the former differs considerably from that of the two latter. Further discussion on this point will be submitted elsewhere.

In addition, the vertical distribution of salts varies in different groves under the same saline irrigation supply. (Compare the data from groves $\mathrm{O}$ and $\mathrm{C}$, tables 4 and 6.) It is not possible at present to explain these variations. Differences in the amounts of water applied, in cultural operations and in the degree of compactness of the subsoil, are probably among the most important factors.

While large portions of these groves have been severely injured, it is interesting to note that the effects have not been uniform over the entire area that has been irrigated with saline water. In som: places, little or no effects were evident in 1918, and again in 1919 the degree of injury was still much less pronounced in certain places than in others. It is important, however, that some of the trees which were healthy in 1917 have since begun to show definite signs of injury. Soil samples have been drawn from among the severely injured trees of the grove (B) and from an area of the same grove where the trees have been only slightly injured. Analyses of these samples are submitted in table 7 .

The results show that the subsoil below the second foot of the severely injured area contains considerably more salts than in the less injured portion. Especially is this true of the chlorine and sodium, the two constituents that seem to be most responsible for the injury in these groves. These variations are probably due to inherent differences in the physical nature of the subsoil which are such as to modify the rates of penetration and accumulation of salts. At any rate, it is interesting that the more severe injury has taken place where the greater amounts of salts have accumulated. As already pointed out, the least affected portions of this grove have now begun to show definite injury. It is highly probable that the injury will become severe over the entire orchard if the use of the present irrigation supply be not discontinued.

As bearing further on the variability of the effects of saline irrigation water, studies have been made on the chemical reactions that take place when salts are added to soils. It has been found that alkali salts 
have the power of reacting with heavy types of soils to a greater degree than with sandy soils. The reactions result in removing limited amounts of sodium from solution and bringing into solution corresponding amounts of other bases, composed mainly of calcium. The physical arrangement of the soil particles also undergoes alteration. In view of the fact that soils are extremely variable, it is not surprising, that the effects of irrigation have not been uniform over a given grove.

Analyses of two irrigation waters from Tulare County are also reported in table 1 (Nos. 103 and 105). They contain unusually large amounts of salts. Information at hand does not made it possible to state the exact length of time these waters have been applied. The wells from which the samples were drawn were deepened about four years previously and there is some evidence that water of a radically different character was obtained as compared with that originally supplied. It is probable that one of these wells (No. 103) supplied fairly pure water previous to being deepened. The orange trees to which these waters have been applied are approximately twelve years old and have shown severe injury during the past two years.

Soil samples were drawn from these groves and also from adjacent unirrigated fields apparently similar in every way to the soils in the groves. One of these has been used for grain for a number of years, the other still remains in its native state. The soil of one of these groves $(\mathrm{T})$ is of a sandy loam character most of which is underlaid with a dense hardpan at a depth of from two to three feet. The other is located on the heavy type of soil, belonging to the Porterville clay loam adobe series, locally known as "dry bog:" The analyses are reported in tables 8 and 9 .

The data confirm the results obtained in the study of the groves located near Riverside. By comparing the irrigated with the unirrigated soils, it is seen at once that the irrigation has greatly increased the amounts of soluble salts in the soil. While the concentration of practically every constituent has been increased, the chlorine and sodium have been increased to the greatest extent. Comparison of the soil analyses with those of the irrigation waters shows that those constituents present in the water in greatest amounts have accumulated in the soil to the greatest extent. The rates of increase, however, are not proportional to the composition of the irrigation water, owing in part, at least, to the fact that citrus trees absorb large amounts of certain constituents, and only small amounts of others. As will be shown elsewhere, citrus trees do not absorb sodium salts to any great extent, but absorb relatively large amounts of calcium. 
It is interesting to note in this connection that navel orange trees are being grown on one portion of each of these groves, and Valencia oranges on another. In each case, the navels were injured in a shorter period of time than the Valencias. In fact, some of the Valencias of grove $\mathrm{T}$, located in a portion of the field where the soil is six or more feet deep, have not as yet been severely injured, but even that portion of the Valencia trees located on shallow soil similar to the navel area have been less severely injured than the navels. In grove $\mathrm{H}$, the Valencias were much less severely injured in 1918 than the navels. It is important to state, however, that many of the Valencia trees in the latter grove have shown severe injury in 1919. These facts, together with observations in other localities, indicate that Valencia oranges are more resistant to alkali than navel orange trees. But it must not be concluded that the former are highly tolerant of alkali, for such is not the case. The use of irrigation water containing alkali salts will ultimately produce injury to either variety, it being mainly a matter of the length of time.

A lemon grove located near San Diego has also been studied. The trees are about sixteen years old and have been irrigated from the time of planting with saline water No. 689. During the past two or three years, a portion of the trees have shown signs of injury, many of them severely so. Most of the older leaves throughout the grove have turned yellow around the margins and brown at the tips. A large proportion of the leaves have fallen in certain places, the smaller shoots have died and the economic value of some of the trees has been greatly impaired.

Referring again to the table of water analysis, it will be seen that the irrigation water (table 1, No. 689) contains considerable amounts of alkali salts, being composed in this case largely of sodium chloride. Soil samples were drawn from this grove to a depth of two feet and also from an adjacent unirrigated field. Their analyses are given in table 10. In harmony with the results already discussed, it is shown that the concentration of salts has been materially increased as a result of irrigation. The unusually high soluble potassium content of the first foot of the irrigated soil is especially noteworthy and is probably due to the liberal use of fertilizers and manure.

The irrigation waters discussed above contain relatively large amounts of salts. Some of them contain amounts of alkali salts that might reasonably have been expected to produce injury. Under the conditions of soil and subsoil, as they exist in these groves, it would have been surprising indeed to find that injury had not been produced by these waters. It is interesting in this connection that the effects 
produced by the irrigation waters discussed above are quite similar to the effects produced at Corona by water from Lake Elsinore more than wenty years ago. The analyses reported by Loughridge also show that the salt content of Lake Elsinore was actually less than that of some of the present supplies. It would seem that the unfortunate experience at Corona has either been forgotten or largely overlooked by citrus growers.

In addition to the above and a considerable number of other saline irrigation supplies, that are at present being applied to certain citrus groves in California, there is a much larger quantity of the irrigation water that contains somewhat smaller amounts of alkali salts. In view of the economic aspects of this phase of the subject, it is a matter of interest to study the effects of this latter class of waters. For this purpose, a lemon grove has been chosen. While the irrigation supply in this case has been drawn from more than one source, the proportions of which have varied from time to time, the analysis given in table 1 (no. 150) probably represents the average composition of the water. It contains considerably less alkali than the irrigation waters discussed above. As judged by current standards, this water would certainly not be considered to be excessively saline.

The lemon trees, now twenty years old, grew thriftily and produced heavy crops of fruit for many years. During the past two or three years, however, some of them have begun to decline. The older leaves have turned yellow or brown and have fallen excessively in the winter and spring. Many of the trees have lost their former thrift and the yields and quality of the fruit have been considerably reduced, in spite of the fact that reasonably good care and liberal amounts of manure and other fertilizers have been applied.

Soil samples have been analyzed from this grove, and also from an area near by that has been under irrigation with water from the same source for only two years. The results are submitted in table 11. The data show that the total soluble matter has been very materially increased as a result of the longer period of irrigation. Considerable amounts of sodium salts, composed principally of the chloride, have accumlated in the soil. Sulfate has also increased considerably. It is again found that the greatest increases have taken place among those constituents that are absorbed by lemon trees in least amounts and have, at the same time, been added in greatest amounts in the irrigation water.

As might have been predicted from the analysis of the water, it has required a longer period of time to effect a given increase in the concentration of salts in this grove than has been required where some 
of the more highly saline waters have been applied. The data show, however, that the alkali content of the soil may ultimately reach a harmful concentration where irrigation water is applied that contains only a relatively low concentration of alkali salts.

It should not be inferred that the application of water similar to sample No. 150 will always produce the same degree of injury; certain other lemon groves of approximately the same age have been irrigated with the same supply as grove (L), which do not, as yet, show any apparent injury. Samples of soil from these groves have not been analyzed.

Taken in their entirety, the above investigations show a remarkably close relationship between the composition of the irrigation water, on the one hand, and the accumulation of alkali salts and the condition of the orange and the lemon trees, on the other. In every case we have studied, where saline irrigation water has been applied for a period of years, alkali salts have accumulated in the soil and the citrus trees have been injured in consequence. The rates at which salts have actually accumulated vary, however, in different soils, depending on (1) the composition of the water, (2) the amounts applied, and (3) the freedom with which it penetrated into the subsoil.

It must be apparent from the above discussion that, although the content of alkali in an irrigation water may not be directly injurious, the time may come after it has been applied for a period of years, when exceedingly harmful amounts of salts will accumulate as a result of evaporation and that sooner or later injurious concentrations may even result from the use of only slightly saline water. The more freely the water penetrates into the subsoil, the greater will be the tendency for the salts to be leached down below the roots of plants, but it must not be concluded that saline water can be applied with impunity to a porous soil, for such is not always the case. Even here injurious concentrations may accumulate. As will be shown elsewhere, injury may be produced by lesser amounts of alkali in a light sandy soil than in heavy soil. It should be understood that sufficient amounts of water to leach the soil effectively are rarely applied in any section of California and especially is this true in the citrus groves where the furrow system of irrigation is used and the supply of water is limited.

\section{THE GROWTH OF CITRUS TREES ON ALKALI SOILS}

It is quite immaterial, so far as the well-being of citrus trees is concerned, or of other crops for that matter, whether alkali be introduced into the soil as a constituent of the irrigation water, or whether 
it accumulate there as a result of other agencies. The net effects will be similar, provided the concentration and proportions of the soluble constituents in contact with the roots be the same.

Several groves have been studied where alkali salts either occurred originally or have been brought up recently by capillarity, due to a high water table. The results have revealed some information additional to that set forth above, which seems to be of sufficient interest to warrant brief discussion.

A twenty-year-old lemon grove located near San Diego, that has been irrigated with reasonably pure water the greater portion of the time, has been studied. During the past few years, the trees have become less thrifty than formerly. Many of the older leaves have become yellow or brown in irregularly shaped areas around their margins and have fallen excessively at certain times. Some of the leaves are variegated and show the usual symptoms of mottle leaf. The yields and quality of the fruit have also depreciated.

Soil samples to a depth of four feet have been analyzed, and the results are recorded in table 12 . The data show that this soil contains considerable amounts of soluble salts of which sodium is the predominant basic constituent. In this case, however, a considerable portion of the sodium, especially in the third and fourth feet, must occur in combination other than the chloride, since the chlorine content is insufficient to combine with all of the sodium present. The data indicate that considerable amounts of both sodium sulfate and sodium bicarbonate occur in the subsoil layers. The water table is many feet below the surface and it is probable that a large portion of the salts accumulated in the subsoil previous to modern agriculture, although the irrigation water may have tended to increase the amounts present.

It is especially interesting that the roots of the lemon trees have not penetrated deeply in this soil, more than 95 per cent of them being within eighteen inches of the surface. There is probably some connection between this fact and the higher concentration of alkali salts found in the third and fourth feet.

The above discussion should not be interpreted to mean that a definite degree of injury to a given variety of citrus trees can always be predicted with certainty from a single soil analysis. On the contrary, other factors are evidently involved in the problem that have not yet been fully evaluated. The following discussion is of interest in this connection.

Local areas occur in a Valencia orange grove near Garden Grove in Orange County where many of the trees have been severely injured by alkali brought up as a result of a temporarily high water table in 
the winter and spring of 1916 . The water table receded within a few months, but the alkali salts remained in the soil. A considerable number of the trees have recently died, and all of them in certain areas became excessively chlorotic, following the rise of alkali.

Soil samples have been drawn from an area where the orange trees have died and also from among healthy trees near by, the analyses of which are submitted in table 13 . The results show that a high concentration of a number of salts occurs where the trees have died. The amounts of chlorine, sulfate, sodium and calcium are all excessive, extremely so in the case of sulfate. The concentration is undoubtedly prohibitive to orange tree growth.

On the other hand, the concentration of soluble sodium in the soil where the trees still remain healthy is very much greater than was found in some of the orange groves where severe injury has been produced by saline irrigation waters. In this case, however, the sodium occurs largely as sulfate and bicarbonate, whereas the chloride predominated in the former case. On the whole, the results obtained in this investigation indicate that sodium chloride is much more toxic to citrus trees than sodium sulfate or sodium bicarbonate, which is in agreement with the conclusions of Hilgard.

An eight-year-old Navel orange grove near Bakersfield, portions of which have been severely injured by alkali, has also been studied. Analysis of soil samples (table 14) reveals a very high concentration of salts where the trees have been severely injured. With the exception of the first foot of this soil, the concentration of chloride is not excessive, but sodium sulfate occurs in large amounts. Unusually high nitrate also occurs in the first foot. This soil is also supplied with large amounts of soluble calcium, the main portion of which occurs as the sulfate (gypsum). Extremely large amounts of gypsum occur in the third, fourth and fifth feet.

The analysis again shows a high soluble sodium content in the soil where the orange trees are normal, but again the chlorine is low. In the first three feet, the sodium is largely combined as bicarbonate. In the second and third feet, considerable amounts of the normal carbonate of sodium also occur.

It will be noted that the fourth, fifth and sixth feet of this soil contain extremely high concentrations of soluble salts, composed mainly of calcium sulfate and sodium sulfate. The roots of the healthy trees are largely confined to the upper two feet of this soil, and so long as they remain there and the alkali does not rise, it is possible that satisfactory growth will result. It is highly probable, however, that the salts will tend to rise as a result of capillarity and 
every precaution should be taken to reduce evaporation to the lowest point possible and thereby retard the rise of salts.

It should be pointed out that a number of the soils studied, where citrus trees have been severely injured by alkali, contain abundant supplies of the usual plant foods. The soluble potassium, nitrate and phosphate have been found to be present in abundance in a number of those soils. It is highly improbable, therefore, that the lack of plant food has contributed to the unhealthy condition of the trees, or that the use of commercial fertilizers will effectively overcome the injury. However, it should be stated that there is some evidence that an abundant supply of plant food does enable citrus trees to overcome small amounts of alkali. On the other hand, it is reasonably certain that no amount of ordinary fertilizer will be able to rejuvenate the trees where large amounts of alkali occur.

\section{THE EFFECTS OF SODIUM NITRATE}

Investigations at the Rothamsted Station in England, at the Pennsylvania Station in this country, and elsewhere, have been interpreted to mean that the continued application of sodium nitrate contributes to the formation of carbonates in soils. The presumption has been that sodium carbonate is formed through the selective absorption of the nitrate $\left(\mathrm{NO}_{3}\right)$ ion by the crop and the union of the sodium with the ubiquitous carbon dioxide of soils. We are not aware that this assumption has been conclusively proved, the published evidence being more suggestive than conclusive.

While we deem it to be highly desirable to know just what compounds actually exist in a given soil, and recognize that dissimilar effects are likely to be produced by different salts of the same base, it is nevertheless true that any salt of sodium is an alkali salt. In view of the possibility, as suggested above, that sodium nitrate may contribute to the formation of sodium carbonate (black alkali) in soils, a substance commonly regarded as injurious to plant life, and that there is evidence that citrus trees may be abnormally affected by high concentrations of sodium, whatever its combination, it is of interest in this connection to study the effects of sodium nitrate.

Relatively large amounts of sodium nitrate have been applied to citrus groves in different localities in California. The fertilizer plots of the Citrus Experiment Station at Riverside afford material for the study of the effects. One of these plots $(H)$ has been fertilized exclusively with sodium nitrate for the past twelve years. For the past six years, approximately 900 pounds have been applied per acre 
per annum. Previously, and especially during the first few years of the experiment, lesser amounts were applied. The total amount that has been applied as an aggregate for the twelve years is 7944 pounds per acre. While the amounts applied have undoubtedly been excessive during the past five years, as is shown by the soil analysis, the amounts of nitrogen applied are not in excess of that sometimes applied by practical citrus growers, who occasionally apply as much as 1000 pounds of sodium nitrate per acre during a single season.

The control plots (B) and (M) lie adjacent to the sodium nitrate plot. Each plot contains six Navel and six Valencia orange trees, and six Eureka and six Lisbon lemon trees. All of them have been irrigated and cultivated as nearly alike as possible. During the first five or six years of the experiment, the growth of the young trees of each variety was markedly stimulated by nitrate of soda. The soil is notably deficient in organic matter and nitrogen and the successful culture of non-leguminous crops requires the addition of considerable nitrogen.

While the growth of the trees was notably stimulated by sodium nitrate during the first few years of the experiment, and healthy, normally appearing trees were produced, since that time excessive mottle leaf has appeared on every tree in this plot. The mottling here became so severe during the past two or three years as to render the trees wholly unprofitable. No marketable fruit whatever is now produced by these trees.

Soil samples from the control and sodium nitrate plots, taken to a depth of six feet in June, 1919, show the effects that have been produced (table 15). The composition of the soluble matter in the soil has been greatly changed as a result of applying nitrate of soda. The total soluble matter has been increased more than twofold in every foot section down to and including the sixth foot. Among the individual constituents, the sodium and nitrate have been most markedly increased. The bicarbonate has also been increased to a limited extent, although not greatly, but the soil of this plot has not accumulated any soluble normal carbonate.

This soil has now accumulated a considerable amount of alkali merely as a result of applying sodium nitrate as a fertilizer for a period of twelve years. Its suitability for the growth of citrus trees has been destroyed, or at least seriously impaired. The alkali in this case is largely sodium nitrate, a substance of unquestionable value as a fertilizer in humid climates and possibly so under certain soil and climatic conditions in the semi-arid west. 


\section{THE EFFECTS OF SALINE IRRIGATION WATER AND $\mathrm{Na} \mathrm{NO}_{3}$ ON THE REACTION OF SOILS}

In view of the widespread belief that sodium carbonate (black alkali) and sodium bicarbonate are the most toxic constituents that occur in alkali soils and of the possibility that the injury to the groves discussed above may have been due to, or at least associated with, excessive alkalinity ( $\mathrm{OH}$-ion concentration), the reaction of a considerable number of these soils has been determined by means of the hydrogen electrode.

It has been found that the use of saline irrigation waters Nos. 119, 642 and 643 , has not increased the alkalinity of the soil over and above that occurring where good irrigation water has been applied. In each case, the soil is distinctly alkaline in the chemical sense of the term, but not appreciably more so where the saline water has been applied.

In the comparisons of unirrigated soil with soil that has been irrigated with saline water, it has been found that in two cases, soils $\mathrm{T}$ and $\mathrm{Y}$, there appears to have been an appreciable increase in alkalinity as a result of irrigation, while in the case of soil $\mathrm{H}$, there has been a decrease.

In order to study the effects of sodium nitrate on soil alkalinity, tests have been made on each of the control plots (B and $\mathrm{M}$ ) that lie adjacent to the sodium nitrate plot $(\mathrm{H})$. The results leave some doubt whether the reaction has been materially changed as a result of applying sodium nitrate. It should be pointed out, however, that the soil of each of these plots is distinctly alkaline and it does not follow from these results that the application of sodium nitrate to an acid soil might not tend to lower the acidity.

A determination of the reaction of other soils not reported herein has shown equally as high a degree of alkalinity (OH-ion) where healthy citrus trees are being grown, as in the severely injured groves. We are inclined to conclude, therefore, that excessive alkalinity is not the cause of the injury, either in the case of saline irrigation waters, or where sodium nitrate has been applied as a fertilizer. Excessive concentration of sodium as such, together with the relationships it bears to the concentration of other constituents present, is probably more fundamentally responsible for the injury.

\section{DISCUSSION}

The results of recent investigations establish the fact that some of the irrigation waters in use at the present time on the citrus groves of California are highly charged with alkali; others contain somewhat 
lesser amounts, while a much larger proportion contains intermediate quantities of salts. Fortunately, however, a very large proportion of the irrigation water is highly satisfactory in quality.

It has been found that a considerale number of citrus groves located in several districts in California have already been severely injured by alkali and that a large percentage of the injury is due to the irrigation water.

The comments of Hilgard made in 1900 relative to the use of saline irrigation water may be appropriately quoted at this time $:^{6}$

Means and Gardner ${ }^{7}$ have called attention to the fact that excessively saline irrigation waters have been applied to the soils of certain portions of the Pecos Valley, New Mexico, and that severe damage has been produced as a result. In discussing this problem in 1899, they said: "The soils were shown to contain originally only small quantities of alkali salts in their natural state, but at present there are areas containing great quantities of such salts. The presence of this alkali may, in nearly all cases, be attributed mainly to the salt which is contained in the irrigation water... The character of the water is the most serious difficulty in the way of profitable irrigation. To develop a new supply of water would be an engineering problem difficult of solution. The use of the present supply is attended with possible loss of crops, especially where the most favorable conditions do not exist."

Forbes $^{8}$ showed that the irrigation waters of the Salt River and other valleys of Arizona are supplying large amounts of salts to the soils. From soil analysis he found that the salt content of the soil had been materially increased in consequence of applying saline water.

6 Calif. Agr. Exp. Sta. Bull. 128 (1900), p. 30.

It would hardly seem necessary to emphasize specially, the danger incurred in irrigation with waters containing unusual amounts of soluble salts; since ordinary common sense clearly indicates the impropriety of increasing the saline contents of soils already charged with them, by the evaporation, year after year, of large masses of saline water. Yet experience has shown that the eagerness to utilize for irrigation whatever water happens to be convenient to good lands, often overcomes both that sense, and warning, given by the published analyses of such waters. Without specifying localities, it may be said that great injury has already been done in California by the disregard of obviously needful caution in this respect. The very slight taste possessed by glauber salt and salsoda does not adequately indicate their presence, even when in injurious amounts; so that frequently a chemical test of the waters is the only definite guide.

7 A Soil Survey of the Pecos Valley, New Mexico. U. S. Dept. Agr., Report 64, pp. 36-76.

8 The River Irrigating Waters of Arizona-Their Character and Effects. Ariz. Agr. Exp. Sta. Bull. 44, 1902. 
Chlorides are undoubtedly the most injurious constituents that occur in the irrigation waters of southern California, but it must not be concluded that other alkali salts can be ignored. In certain localities some of the waters also contain injurious amounts of sulfates and earbonates. Hilgard says, "Unfortunately it is not easy to give absolute rules in regard to the exact figures that constitute an excess of salts for irrigation purposes, since not only the composition of the salts, but the nature of the land to be irrigated, and the frequency of irrigation required, must be taken into consideration." He concluded that 40 grains per gallon (684 parts per million) is the maximum amount of the total mineral matter a water can safely contain, unless the mineral constituents be composed largely of gypsum. But he also said: "When a large proportion of the solids consists of carbonate of soda or common salt, even a smaller proportion of salts than 40 grains might preclude its regular use." We regret to state that a considerable number of irrigation waters contain salts in excess of this limit, some of them greatly so.

It has also been shown that the continued application of nitrate of soda may bring about an increase in the amounts of alkali in the soil. It is true, the amount of nitrate that has been applied to the experimental plot we have studied is excessive and the results might have been different on other soil or even on the same soil, had it been treated differently in other respects. If nitrate of soda be applied in moderate quantities to a porous soil, especially where the rainfall is heavy, or if used in conjunction with manure and cover crops, it is highly probable that the sodium will be leached more deeply than it has been on the experimental plot at Riverside.

However, it is especially important for farmers to understand clearly that citrus trees, as well as many other crops, do not absorb more than very limited amounts of sodium, and that wherever nitrate of soda be applied, either in combination with other fertilizer constituents or alone, the sodium will, for the most part, be rejected by the crop and left in the soil. This sodium remains mostly in soluble form and contributes directly to the alkali content of the soil.

All sodium salts are really alkali salts. As has been repeatedly stated, small amounts of none of them are injurious, and in the case of the nitrate, limited amounts undoubtedly stimulate the growth of practically all crops; but unless drainage effectively leach the salts from the soil, the continued application of sodium nitrate, or of saline irrigation water, will ultimately produce a harmful concentration of alkali in any soil. 
It is also a matter of practical importance, that the repeated application of any sodium salt to soils, followed by leaching with irrigation water, or rains, tends to reduce the porosity of the soil and thereby restricts the movement of the water through it. Sodium carbonate and sodium bicarbonate probably produce this effect to a greater extent than the other common sodium salts, but all of them produce this effect to an undesirable extent. The experimental plot to which nitrate of soda has been applied, has become badly puddled, and the poor physical condition of the subsoil in a number of the groves where saline waters have been applied, form one of their striking characteristics. The surface soil in some of these groves has become exceedingly baked, so much so as to be readily detectable by merely walking over it. Hence, the effects of alkali are not wholly determined by the concentration of salts in the soil. The adverse physical conditions must also be considered.

Therefore, wherever nitrate of soda or saline irrigation water be used in regions of light rainfall, especially if applied for any considerable length of time, it is important for farmers to understand that the soil must be kept open and porous. This ean probably best be accomplished by growing deep-rooted cover crops and plowing under organic materials, such as manure or bean straw.

While ordinary irrigation and rains tend to leach more or less alkali down below the reach of citrus roots and probably accomplish this end quite effectively in some soils, our investigations show that the application of saline water has resulted in materially increasing the amounts of alkali within reach of the roots of the citrus trees. The soil types and climatic conditions of these groves vary widely. Some of them, not reported above, occur in the districts of comparatively heavy rainfall and on soils ordinarily considered to be naturally well drained.

As suggested above, the irrigation supplies rarely contain enough alkali to harm citrus trees directly. So far as we have been able to learn, no detrimental effects occurred in any of the groves until after the saline waters had been applied for a period of years. The injury came about rather through the concentration resulting from the accumulated residue, left by the evaporation of repeated applications of water, as was pointed out by Dr. Hilgard many years ago.

An excess of chlorides causes the tips and margins of citrus leaves to become yellow or brown, followed by defoliation. Sometimes a large portion of the leaves fall and the young, tender shoots may be killed. An excess of sulfates and bicarbonates, on the other hand, is more likely to stunt the growth of the trees and cause the leaves to become 
chlorotic. More or less mottle leaf may also occur. Lemon trees are apparently injured by lesser amounts of alkali than oranges.

On the whole, the observations and conclusions of Hilgard and Loughridge have been strikingly confirmed. It has again been shown that citrus trees are quite sensitive to alkali and especially to sodium chloride. It is a matter of practical importance for citrus growers to recognize this fact, for sodium chloride is the one constituent most commonly found in irrigation waters that are drawn from wells in the citrus sections of California.

As for the treatment of the injured groves, nothing more than the most general suggestion can be offered at present. Where saline irrigation water is being applied, the first consideration should be to secure an adequate supply of pure water. In fact, so long as the application of saline water be continued, it will be difficult to overcome the harmful effects by any method that may be devised.

As suggested by Forbes ${ }^{9}$ an occasional flooding may improve the conditions, by leaching the salts below the reach of the roots, but before flooding be undertaken, the irrigator should assure himself that the subsoil is of such character as will permit deep penetration of the water and allow it to drain away. Otherwise, his efforts will be wasted. After the salts have been washed down below, the soil should be thoroughly cultivated in order to reduce evaporation and thereby check the rise of salts.

Where saline water is the only irrigation supply that can possibly be obtained, it may be found desirable, in some cases at least, to discontinue the furrow system of irrigation entirely and adopt some form of basin or flooding irrigation instead. By that means, the tendency will be to leach the salts down into the subsoil and possibly below the reach of citrus roots. The success of such a scheme will depend largely on the nature of the subsoil drainage and the thoroughness with which it is executed. In addition, the leaching effects of the winter rains should be taken advantage of to the greatest extent possible. As a means to this end, the soil should be put into such condition previous to the rainy season, as will prevent surface run-off and enable the rain water to penetrate deeply.

It should be borne in mind, however, that alkali salts are being driven down into the subsoil and that there is a constant danger of the salts rising up around the roots. Furthermore, the continued addition of such large amounts of salts as occur in some of the irrigation waters, will materially increase the salt content of the natural

9 Ariz. Agr, Exp. Sta. Bull. 44 (1902), pp. 167-170. 
drainage water. In localities where the volume of the drainage water resulting from such leaching constitutes any considerable portion of the natural drainage water, the ground water may ultimately become heavily charged with salts as a result. This is especially to be feared where the ground water is rising or is already near the surface. In view of these facts, the application of saline irrigation water should be avoided, whenever possible.

The experience of the growers near Corona, following the use of water from Lake Elsinore, is of special interest at this time. Some of the groves that were severely injured then, have since recovered and have borne profitable crops of fruit, while others have not yet fully recovered. In general, the most effective treatment was found to consist of thorough tillage, plowing down manure and the application of suitable irrigation water.

If good water be applied freely it is probable that the harmful concentrations of salts that have accumulated will be gradually leached down below the reach of the roots and the use of manure, coupled with deep plowing, will gradually restore conditions favorable to growth. As a means of further increasing the porosity of the soil, an application of gypsum may also be desirable. In addition to its floceulating effect, gypsum, and other calcium salts also, seem to ameliorate the effects of toxic concentrations of alkali salts, and enable crops to tolerate concentrations of alkali salts that are prohibitive of normal growth in the absence of an abundance of calcium salts.

While somewhat apart from this investigation, it may be appropriate to state, that a limited study of the amounts of water available to the citrus groves of California leads us to believe that the most promising source from which a supply of really good water can be secured in quantities sufficient to meet the demands of the constantly expanding citrus industry, can be obtained only through concerted effort directed towards the control of flood waters. By the use of suitable check dams, reservoirs, reforestation, and such other devices as will permit the storage of the mountain waters, either above ground or within the water-bearing gravels, an adequate supply of suitable water can probably be obtained. At any rate, the excellent water that falls in the mountains of California, may be so conserved as to augment materially the volume of water now being obtained from them, and thereby make it possible to discontinue the use of at least a portion of the saline water. ${ }^{10}$

10 Acknowledgment is due Mr. A. B. Cummins and Mr. S. M. Brown for analytical assistance rendered in connection with this investigation. 


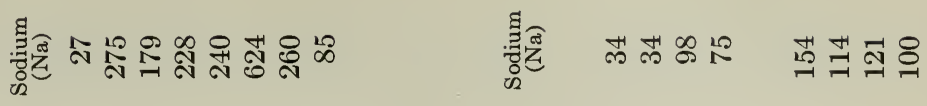

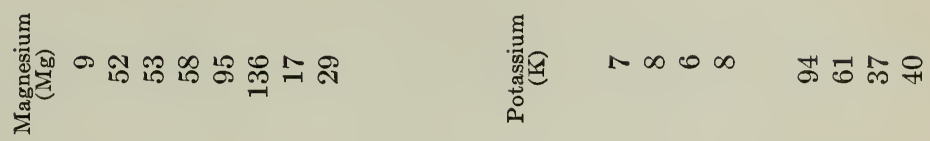

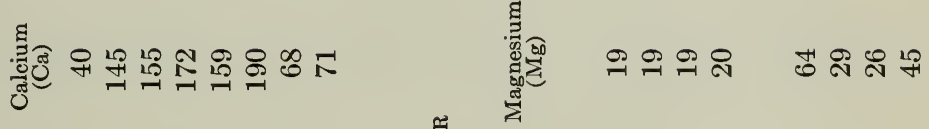

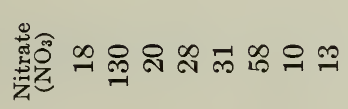

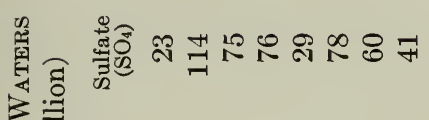

舅

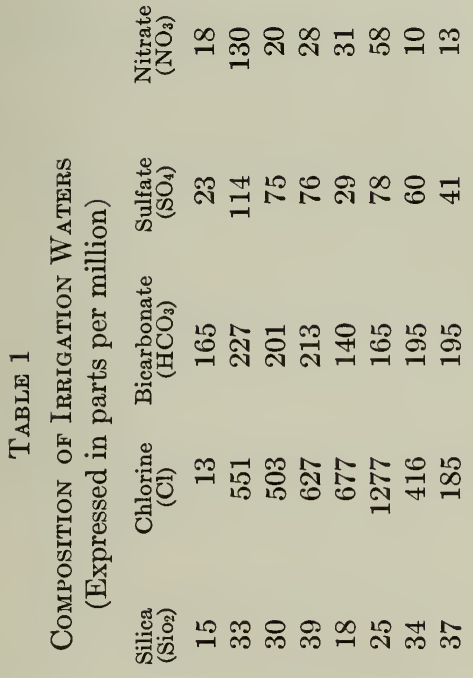

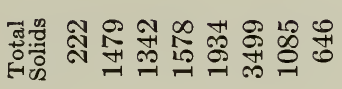

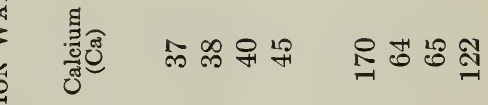

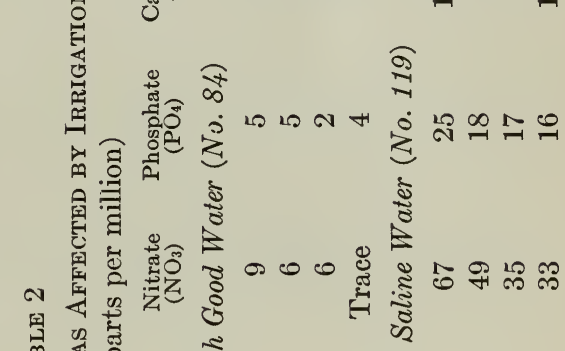

苜.

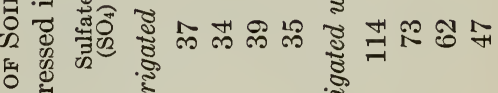

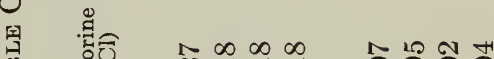

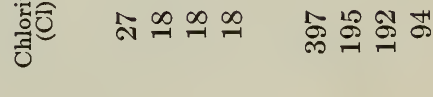

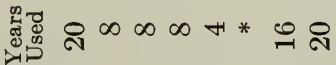

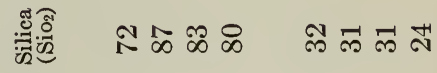

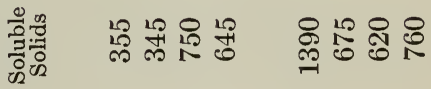

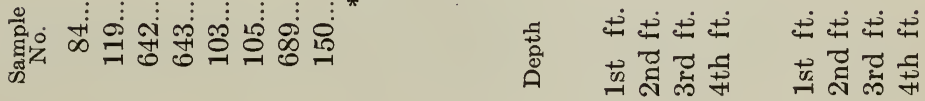




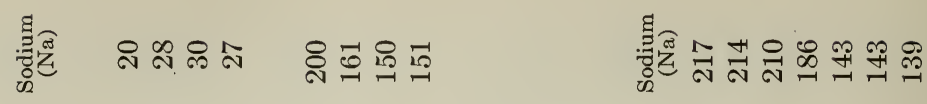

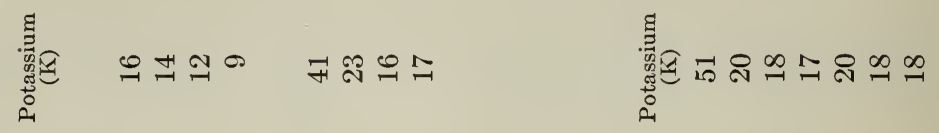

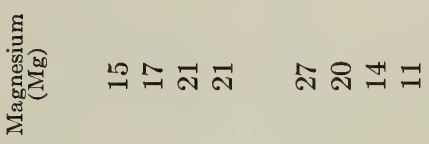

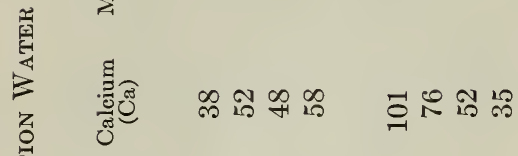

孚

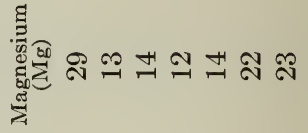

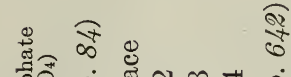

赵

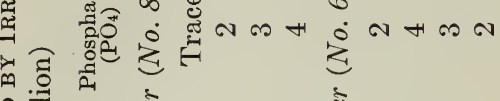

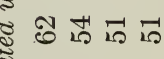

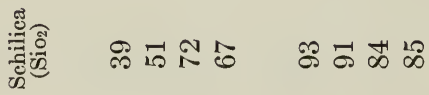

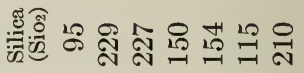

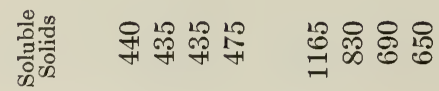

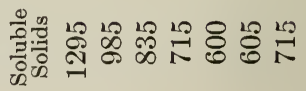




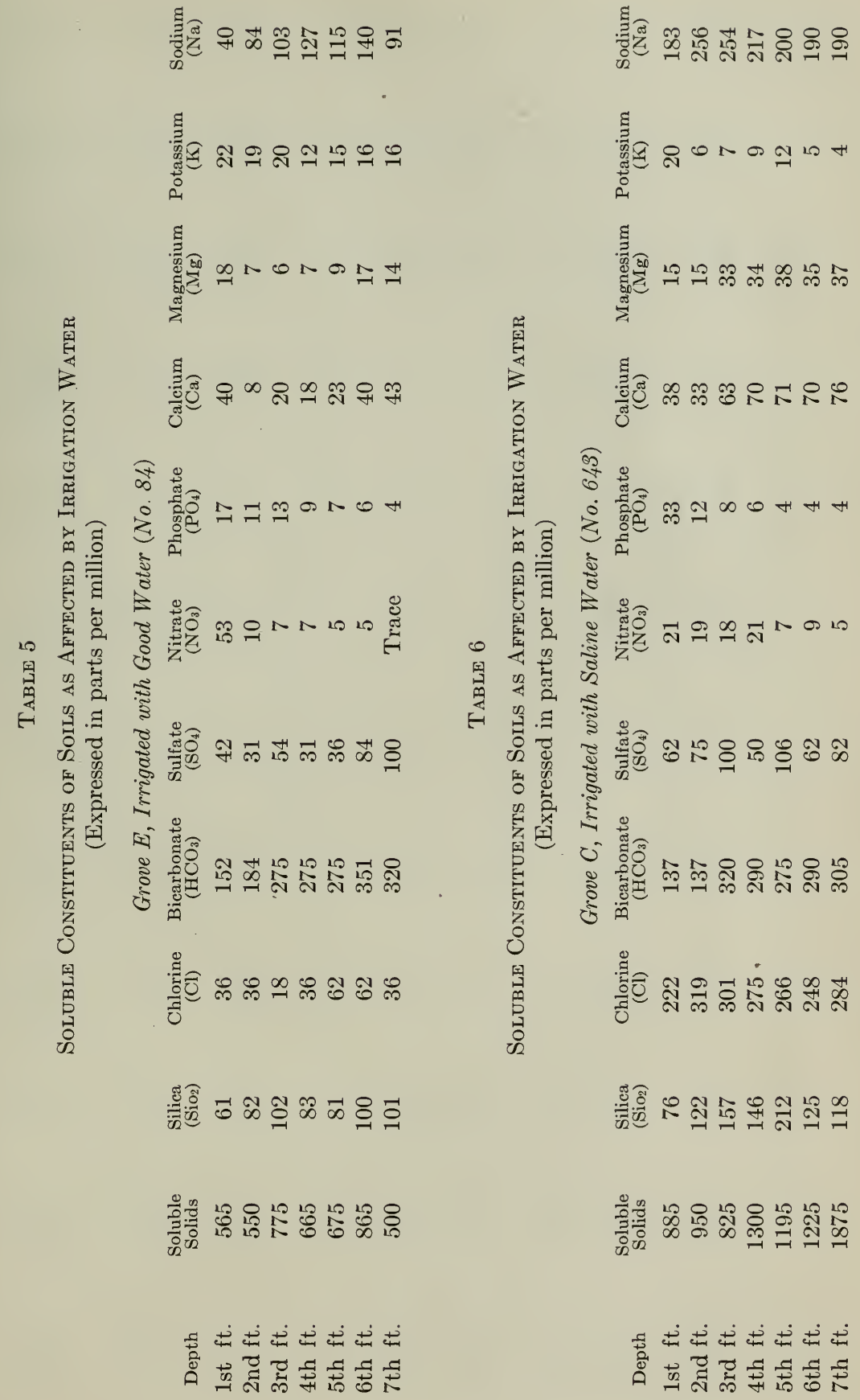




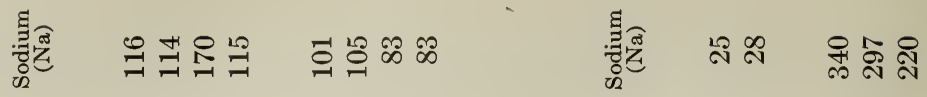

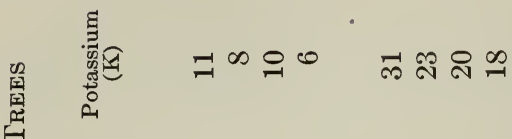

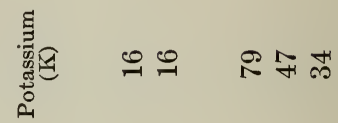

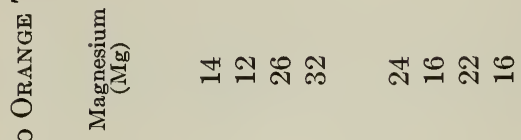
안

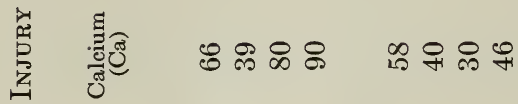

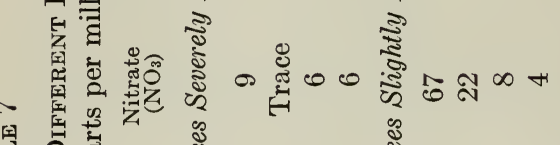

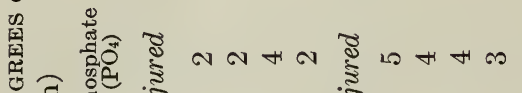
通

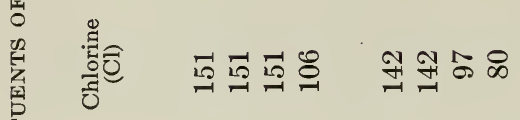

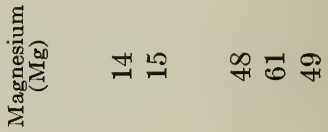

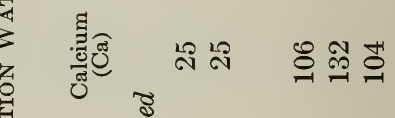

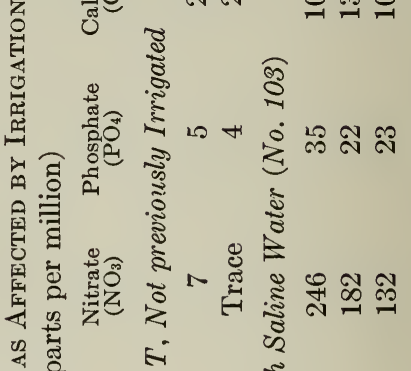

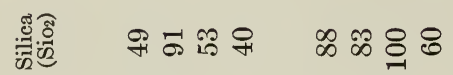

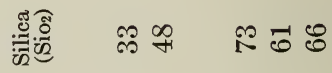

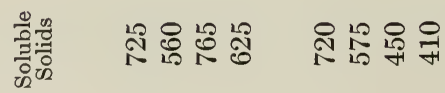

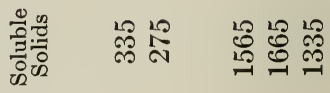




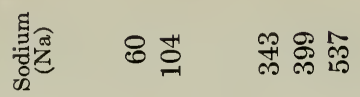

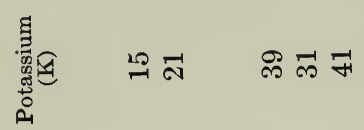

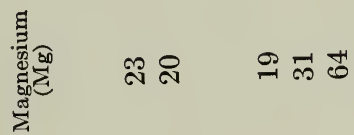

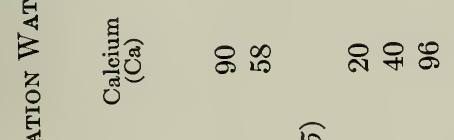

I

要

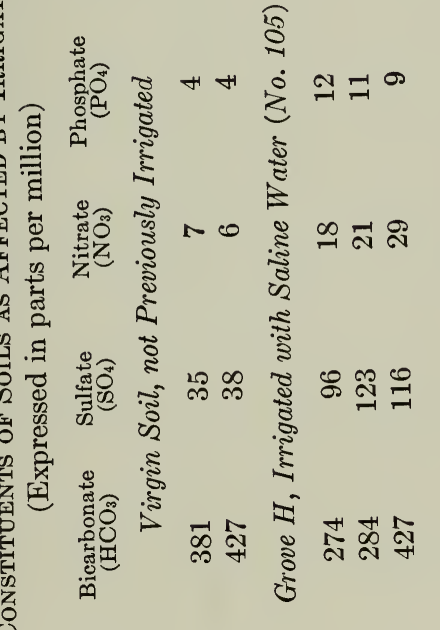

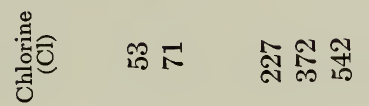

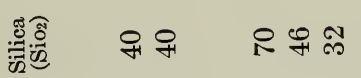

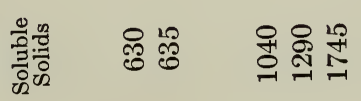

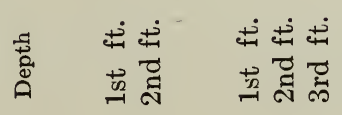

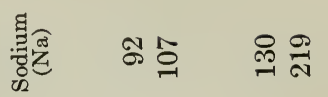

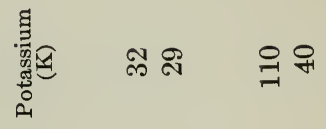

量覆 $0=0$

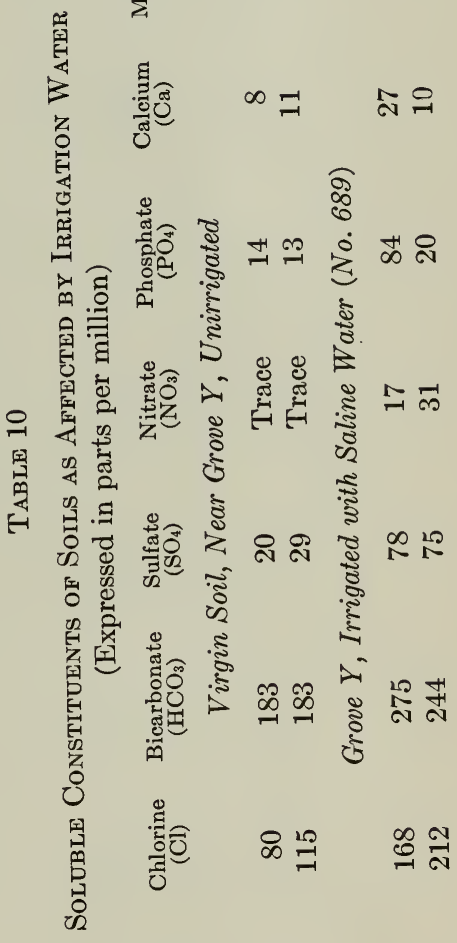

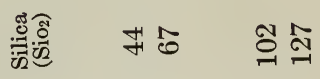

产高高

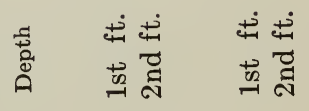




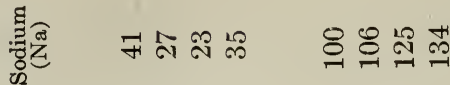

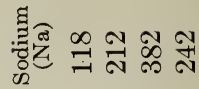

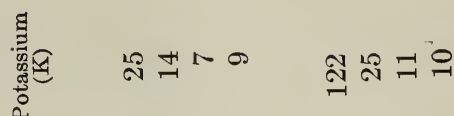

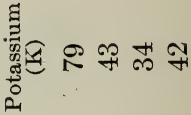

\&

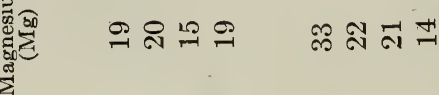

ㅂㅐㅀㅠ<smiles>C=[Si]</smiles>

อุ

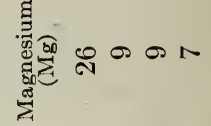

욜

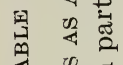

跑:

四

然商

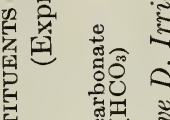

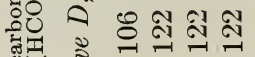

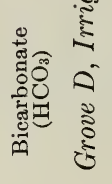

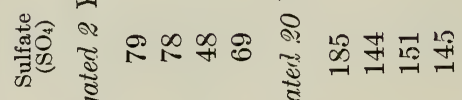

है

$\stackrel{\infty}{\infty} \underset{\sim}{\infty}$

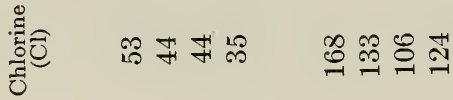

คิ

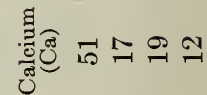

兒

年

国 है

岳

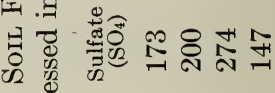

ज्ञ

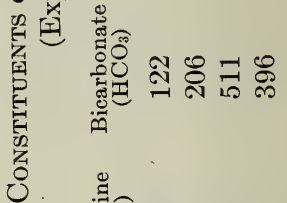

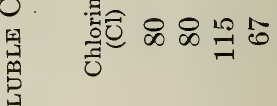

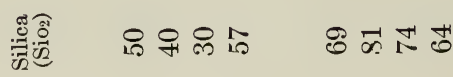

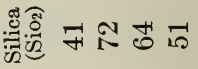

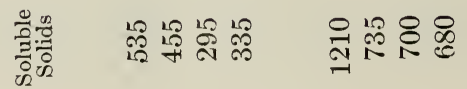

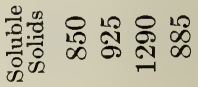

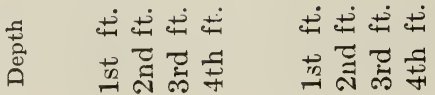

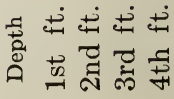




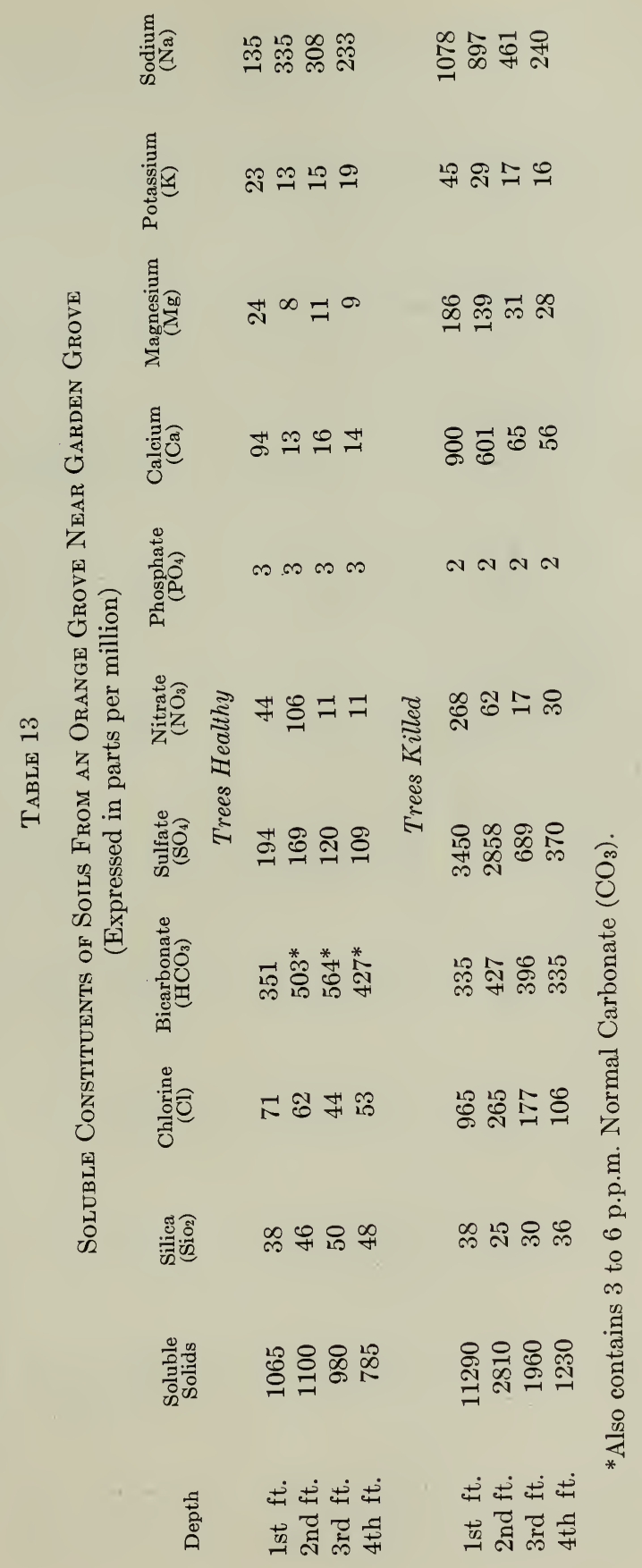




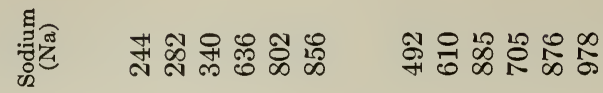

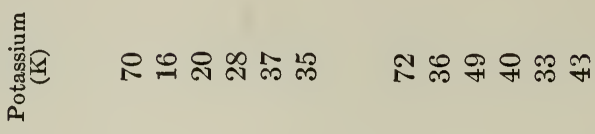

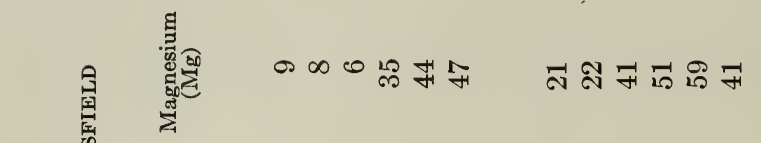

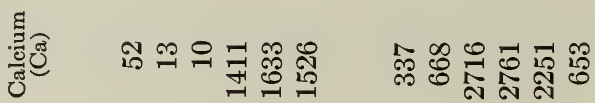

(1)

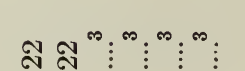
$\Phi 2^{\infty}::_{\infty}^{\infty}: \infty: \frac{\infty}{8}$

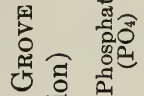
ลก

융유 $\stackrel{\infty}{\infty} \stackrel{\sim}{\sim} \underset{\exists}{\sim}$

옥아윰유믄

国

ब

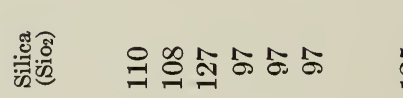
ลำㅇำ

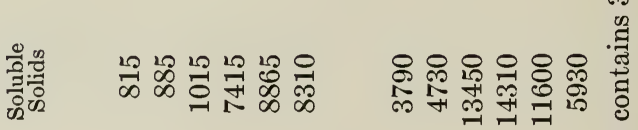

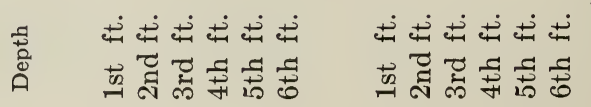




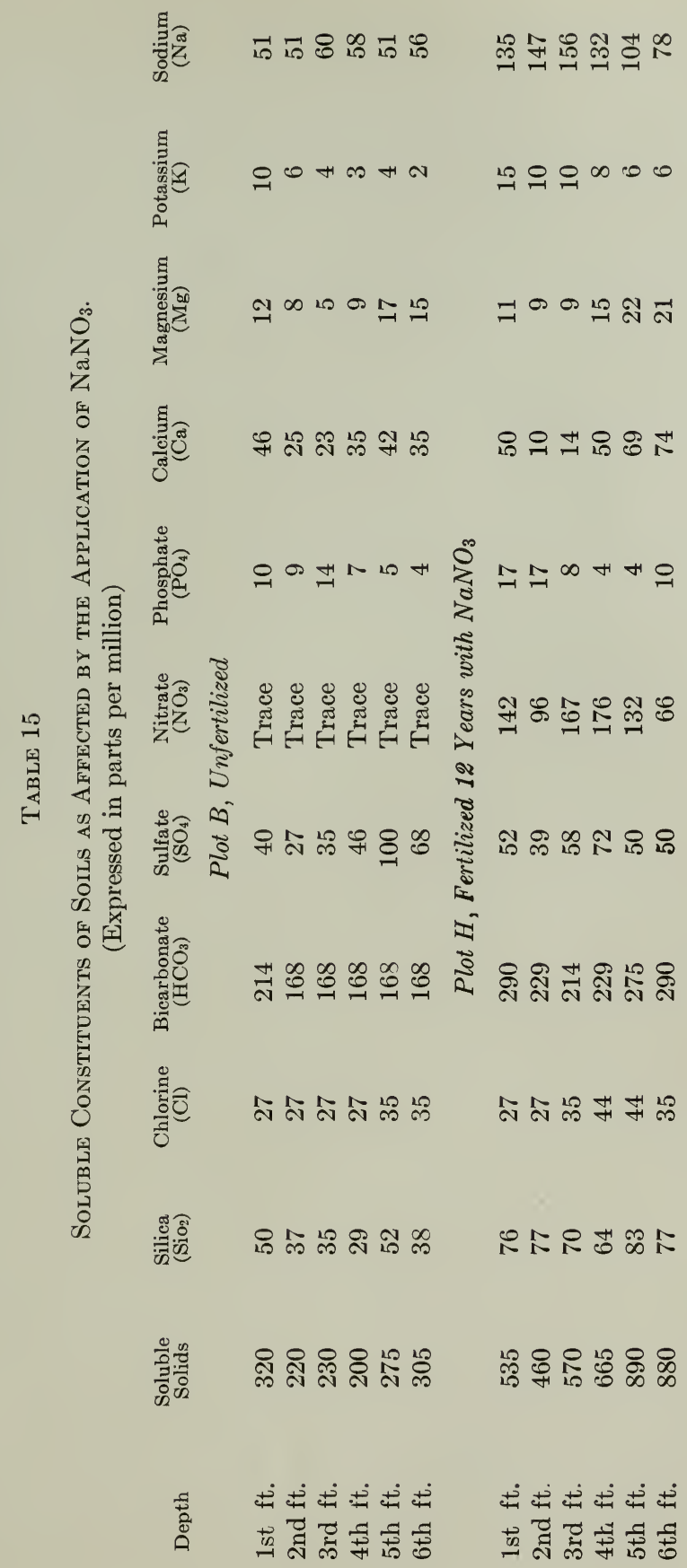


